\title{
Building Lecturer Performance Through Organizational Culture and Work Motivation
}

\author{
Rusmini* $^{*}$ \\ Universitas Islam Negeri Sulthan Thaha Saifuddin, Jambi \\ *corresponding author: rusmini@uinjambi.ac.id
}

\begin{abstract}
:
The study aims to test hypotheses and analyze organizational culture and work motivation influences on the performance of lecturers at the Islamic Education Management Study Program, Faculty of Tarbiyah and Teacher Training, UIN Sulthan Thaha Saifuddin Jambi. This research is a quantitative study, with a survey method with path analysis techniques, namely $R$ Square analysis, testing the partial hypothesis with the $t$ test and simultaneously with the F test, with an alpha of 5\% (0.05). The total population are 30 lecturers. Data analysis was performed using SPSS version 20.0. The results showed that there was a positive and significant influence between organizational culture and work motivation variables on lecturer performance, either partially or simultaneously.
\end{abstract}

KEYWORDS: Lecturer performance; organizational culture; work motivation.

\begin{abstract}
ABSTRAK:
Penelitian ini bertujuan untuk menguji hipotesis dan menganalisis budaya organisasi dan pengaruh motivasi kerja terhadap kinerja dosen di Program Studi Manajemen Pendidikan Islam, Fakultas Tarbiyah dan Pelatihan Guru, UIN Sulthan Thaha Saifuddin Jambi. Penelitian ini merupakan studi kuantitatif, dengan metode survei menggunakan teknik analisis jalur, yaitu analisis $R$ Square, pengujian hipotesis parsial dengan t-tes bersamaan dengan $f$-tes, dengan alpha 5\% (0.05). Total populasi sebanyak 30 dosen. Analisis data dilakukan menggunakan SPSS versi 20.o. Hasil penelitian menunjukkan bahwa terdapat pengaruh positif dan signifikan antara budaya organisasi dan variabel motivasi kerja pada kinerja dosen, baik sebagian atau secara bersamaan.
\end{abstract}

KATA KUNCI: Kinerja dosen; budaya organisasi; motivasi kerja

Copyright (c) Published by Program Studi Manajemen Pendidikan Islam Fakultas Tarbiyah dan Keguruan

Universitas Islam Negeri Sulthan Thaha Saifuddin jambi

Mendalo Darat, Muaro Jambi, 36361, Indonesia 


\section{INTRODUCTION}

Islamic universities with their dynamics are faced with the process of growth and development along with changing times, and currently Islamic universities are aware of their function in society. Islamic universities are an integral part of the country's development. Therefore, the availability of human resources with quality and professional performance is the role of Islamic universities. The Islamic Education Management Study Program, Faculty of Tarbiyah and Teacher Training, UIN Sulthan Thaha Saifuddin Jambi in carrying out its main tasks and functions, of course, must be supported by quality human resources, especially in carrying out the tri dharma in higher education, including education and teaching, research, and service to the community.

A lecturer must understand the task he is doing. Lecturers must also carry out their duties professionally with high responsibility and always improve their quality. The occurrence of an academic atmosphere and culture, especially fellow academics, can develop internal awareness of the academic community. Academic culture as the totality of academic life must be lived, interpreted and practiced by members of the academic community.

Based on a preliminary study at the Islamic Education Management Study Program, Faculty of Tarbiyah and Teacher Training at UIN Sulthan Thaha Saifuddin Jambi, an understanding was obtained about the need to improve lecturer performance, especially in relation to organizational culture and work motivation. Lecturer performance can also be seen from the lecturer's skills, namely through pedagogic competence, professional competence, personality competence, and social competence. Therefore, it is important to relate these variables to the performance of the lecturers, and to know the relationship between these variables, so that there is an increase in the performance of the lecturers.

\section{Performance concept}

The term performance is defined as work performance. Bernardin and Russell in Ahmad. S. Ruki, defines performance as the record of outcomes produced on a specified job function or activity during a specified time period" . The realization of individual achievement results that have potential in terms 
of attributes (knowledge, abilities, skills, expertise) and competencies depends on a good performance management process. Good performance management will help integrate the goals outlined in the organization referring to the results achieved or to the contribution made to the achievements of the organization.

The factors that affect performance, both individual, group, and organizational performance. Individual performance is influenced by factors of knowledge, skills, motivation and the role of the individual concerned, job satisfaction, satisfaction itself is an individual's feeling towards his work. This individual performance will affect group performance, in addition to team characteristics, team closeness, leadership, cohesiveness, team roles, and norms. The performance of this group will affect the performance of the organization. Organizational performance is influenced by various organizational characteristics such as environment, leadership, organizational structure, choice of strategy, technology, organizational culture, and organizational processes.

The form of individual lecturer performance is the realization of the competence possessed by the lecturer. The competencies referred to Constitution No. 14/2005 on Teachers and Lecturers, namely pedagogic competence is the ability to manage student learning, personality competencies are personality abilities that are stable, have noble character, are wise, and authoritative and become role models for students, professional competence is the ability to master broad and deep subject matter, and social competence is the ability of teachers to communicate and interact effectively and efficiently with students, fellow teachers, parents/guardians of students, fellow teachers, and the surrounding community .

Thus, the synthesis of lecturers' performance in this study is the real behavior shown by lecturers when carrying out their duties through education and teaching based on the formulation of indicators of lecturer competencies that have been determined, namely pedagogic competence, personality competence, professional competence, and social competence.

Organizational culture concept

Tony Bush and David Middlewood explain that the concept of culture in education has developed significantly from the 1990 s to the 21st century. Marc Schabracq also explained that the concept of culture is difficult to define. 
This difficulty is given the breadth of the term and the variety of cultures, as well as cultural factors hidden from the eye of the beholder. Edgar H. Scherin stated that culture as an abstraction, a force created in social situations and organizations must be strong. Lack of understanding of the operation of this power, causes the victims of this cultural power . For Beare in Tony Bush, the concept of organizational culture emphasizes the informal aspects of the organization rather than its employee elements. The concept of organizational culture emphasizes the values, beliefs and norms as well as individual perceptions that are unified and directed towards understanding the organization .

For Tony Bush, the cultural model assumes that beliefs, values, and ideologies are at the heart of the organization, while Lunenburg and Ornstein view the culture of an organization as the sum total of beliefs, feelings, behaviors, and symbols as characteristics of an organization . Furthermore, Lunenburg and Ornstein said organizational culture can influence many administrative processes, such as motivation, leadership, decision making, communication and change, even culture affects the organizational structure process, selection process, evaluation system, monitoring and reward system. In other words, culture affects the performance of lecturers and organizational effectiveness . In Fahmi's view, organizational culture is an old habit that is used by work life activities as one of the drivers in improving the quality of lecturers' work. An organization in maintaining culture, must be consistent in applying it continuously to lecturers .

Based on some of the theories above, organizational culture becomes a bureaucratic tradition and practice that must grow in organizations. Organizational culture can be identified with a commitment to enforce a procedure, system, or performance within the organization. Without a strong commitment or culture, the organization will lose management control.

In this study, the constructs of organizational culture in question are values, norms, and beliefs (which include a lecturer's code of ethics, discipline, loyalty, professionalism, and responsibility) as well as ritual and ceremonial aspects (which include coaching, providing examples, creating routine events, and give an assessment). While the research indicators are self-confidence, a 
sense of belonging, positive behavior towards the organization and the form of behavior that is created.

\section{Work motivation concept}

Work motivation comes from two words "motivation" and "work". Motivation from the Latin, "movere" which means to move (push) . Robbins explains motivation as the will to do something and is conditioned by its ability to act in meeting needs . Motivation is interpreted as a person's self-needs that encourage him to carry out activities. Hasibuan stated that motivation comes from the basic word motive, which means a stimulus, desire and driving force for the will to work. Motivation also means providing a driving force that creates work enthusiasm so that they want to work together effectively and are integrated with all efforts to achieve satisfaction .

For Robbins, motivation is a willingness to make high efforts for organizational goals based on the ability to meet individual needs, while needs occur because there is no balance between what is owned and expected. Motivation is a mental strength that is oriented towards fulfilling expectations and achieving goals, while goals are targets to be achieved by individuals . It can be understood that motivation is an impulse that arises from a person, whether consciously or not, in doing something with a specific purpose, and getting satisfaction from his actions. Work is physical and mental activity to do a job . For Fattah, work is an activity in carrying out something .

If combined, then work motivation is a condition that influences, generates, directs, and maintains behavior related to the work environment . Work motivation is a potential force within a person, which can be developed by a number of external forces such as monetary and non-monetary rewards that can encourage positive or negative performance results, depending on the situation and conditions concerned. Thus, work motivation can be understood as something that can generate enthusiasm for work in order to achieve goals. Work motivation of teachers as educators is a condition that makes teachers have the will to achieve the goal of carrying out a task. Work motivation will supply energy to work, direct activities during work, and result in teachers knowing the goals of the organization with their personal goals.

Motivation as a psychological process arises due to factors from oneself due to intrinsic factors such as personality, attitudes, experience and 
education, various expectations, goals that are reached or extrinsic factors that arise due to various sources such as the influence of leaders, colleagues, or other factors that influence more complex. Both of these factors (intrinsic and extrinsic) can arise due to stimulation.

Frederick Herzberg in Wibowo developed a Two-Factor Theory based on 'motivators' and 'hygiene factors'. Hygiene factors are basic human needs, they are not motivating, but failure to get them causes dissatisfaction. Hygiene factors include salary and benefits, working conditions, organizational policies, and status. The motivators are factors that encourage people to get their needs. This factor must be sought by the manager in maintaining lecturer job satisfaction .

Frederick Herzberg's opinion on the two-factor theory can be used as a dimension that reflects as a factor that has a strong influence on one's motivation at work. Work motivation can be understood as encouragement in doing a task with a standard of excellence. So, work motivation is not only an urge to do something, but rather refers to a measure of success based on the completion of a specified task.

It can be formulated that work motivation is an individual's extrinsic and intrinsic drive in doing a better job to achieve goals. The indicators of intrinsic motivation are in the form of achievement drive, recognition obtained, interest in work, sense of responsibility in work, and progress in career, while extrinsic motivation is in the form of institutional policies, supervision, working conditions, salaries and benefits, and interpersonal relationships.

\section{METHODS}

This research was conducted with a quantitative approach, namely the survey method with path analysis technique, with the equation $\mathrm{Y}=\mathrm{Pyxi}_{\mathrm{X}} 1+$ $\mathrm{Pyx}_{2} \mathrm{X}_{2}+\varepsilon$, where $\mathrm{Y}$ is the lecturer performance variable, $\mathrm{X}_{1}$ is the organizational culture variable and $\mathrm{X}_{2}$ is the work motivation variable. The total population is 30 lecturers who teach at the Islamic Education Management Study Program, Faculty of Tarbiyah and Teacher Training at UIN Sulthan Thaha Saifuddin Jambi. The sampling technique uses total sampling. 
Path analysis is used to test the validity and reliability of the instrument with the classical assumption test. Prior to data analysis, the questionnaire was validated and its reliability calculated, then tested for normality, homogeneity, and linearity. Data analysis was performed using SPSS version 20.0. In path analysis, R Square analysis was carried out, partial hypothesis testing (t test) and simultaneous (F test), with an alpha of $5 \%$ (0.05).

\section{FINDINGS}

The equation model of this research is $\mathrm{Y}=\mathrm{Pyx}_{1} \mathrm{X}_{1}+\mathrm{Pyx}_{2} \mathrm{X}_{2}+\varepsilon$. This model is used to test the hypothesis that organizational culture and work motivation partially and simultaneously affect the performance of lecturers. The results of the study show the following:

Table 1. Results of analysis of organizational culture influence (X1) and work motivation $\left(\mathrm{X}_{2}\right)$ on lecturer performance $(\mathrm{Y})$

Coefficients $^{\mathbf{a}}$

\section{motivation (X2) on lecturer performance (Y)}

\begin{tabular}{|c|c|c|c|c|c|c|c|c|c|}
\hline & \multirow{2}{*}{ Model } & \multicolumn{2}{|c|}{$\begin{array}{l}\text { Unstandardized } \\
\text { Coefficients }\end{array}$} & \multirow{2}{*}{$\begin{array}{c}\begin{array}{c}\text { Standardized } \\
\text { Coefficients }\end{array} \\
\text { Beta }\end{array}$} & \multirow[b]{2}{*}{$\mathrm{t}$} & \multirow[b]{2}{*}{ Sig. } & \multicolumn{3}{|c|}{ Correlations } \\
\hline & & B & $\begin{array}{l}\text { Std. } \\
\text { Error }\end{array}$ & & & & $\begin{array}{l}\text { Zero- } \\
\text { order }\end{array}$ & Partial & Part \\
\hline & (Constant) & 52.600 & 27.952 & & 1.882 & .071 & & & \\
\hline 1 & $\begin{array}{l}\mathrm{X}_{1} \\
\mathrm{X}_{2}\end{array}$ & $\begin{array}{l}1.055 \\
.182\end{array}$ & $\begin{array}{l}.262 \\
.267\end{array}$ & $\begin{array}{l}.703 \\
.119\end{array}$ & $\begin{array}{l}4.020 \\
2.683\end{array}$ & $\begin{array}{l}.000 \\
.004\end{array}$ & $\begin{array}{l}.638 \\
.261\end{array}$ & $\begin{array}{l}.612 \\
.130\end{array}$ & $\begin{array}{l}.591 \\
.100\end{array}$ \\
\hline
\end{tabular}

a. Dependent Variable: Y

From the table above, the path analysis coefficient results are $\mathrm{Y}=\mathrm{Pyx} \mathbf{x} 1$ $+\mathrm{Pyx}_{2 \times 2}=0,703 \mathrm{X}_{1}+0,119 \mathrm{X}_{2}$. The results of the path analysis equation can be described, namely the influence of organizational culture (X1) on lecturer performance $(\mathrm{Y})$ is 0.703 or $70.30 \%$, and the effect of work motivation $\left(\mathrm{X}_{2}\right)$ on lecturer performance $\left(\mathrm{X}_{4}\right)$ is 0.119 or $11.90 \%$.

Determinant Analysis (R2)

The magnitude of the influence of organizational culture and work motivation simultaneously on the performance of lecturers can be seen as follows: 
Table 2. Analysis of the coefficient of determination of organizational culture (X1) and Work Motivation (X2) on Lecturer Performance (Y) Model Summary

\begin{tabular}{|c|c|c|c|c|c|c|c|c|c|}
\hline \multirow[b]{3}{*}{ Model } & \multirow[b]{3}{*}{$\mathrm{R}$} & \multicolumn{7}{|c|}{ Model Summary } & \\
\hline & & \multirow[b]{2}{*}{$\begin{array}{c}\mathrm{R} \\
\text { Square }\end{array}$} & \multirow{2}{*}{$\begin{array}{l}\text { Adjusted } \\
\text { R Square }\end{array}$} & \multirow[b]{2}{*}{$\begin{array}{l}\text { Std. Error of } \\
\text { the Estimate }\end{array}$} & \multicolumn{5}{|c|}{ Change Statistics } \\
\hline & & & & & $\begin{array}{c}\text { R Square } \\
\text { Change }\end{array}$ & $\begin{array}{c}\text { F } \\
\text { Change }\end{array}$ & dfi & $\mathrm{df}_{2}$ & $\begin{array}{l}\text { Sig. F } \\
\text { Change }\end{array}$ \\
\hline 1 & $.646^{\mathrm{a}}$ & .417 & .374 & 13.91142 & .417 & 9.662 & 2 & 27 & .001 \\
\hline
\end{tabular}

a. Predictors: (Constant), X2, X1

b. Dependent Variable: Y

From the table above, it is known that the $\mathrm{R}$ value of 0.646 indicates a double correlation between organizational culture, work motivation and lecturer performance. The R Square value of 0.417 explains that the magnitude of the influence given by the organizational culture variable $\left(\mathrm{X}_{1}\right)$, work motivation $\left(\mathrm{X}_{2}\right)$ simultaneously on lecturer performance $(\mathrm{Y})$ is $41.70 \%$. There are other factors that influence the occurrence of lecturer performance, in addition to the variables studied. The contribution from other factors is 0.583 or $58.30 \%$.

Partial effect ( $t$ test) and simultaneous effect (F test)

One-way ANOVA analysis was used to answer the research hypothesis. The statistical hypotheses were tested through t-test and F-test. Based on the coefficient table, $t$-value and sig analysis were used to analyze the partial hypothesis testing, while the F-test through ANOVA especially column F and sig served to test hypotheses simultaneously as follows:

Table 3. $t$ test to test the effect of $\mathrm{X}_{1}$ and $\mathrm{X}_{2}$ Partially Against $\mathrm{Y}$

\begin{tabular}{llll}
\hline \multicolumn{1}{c}{ Variable } & $\mathbf{t}_{\text {count }}$ & $\mathbf{t}_{\text {table }}$ & Sig \\
\hline Budaya Organisational Culture $\left(\mathrm{X}_{1}\right)$ & 4.020 & 1.701 & 0.000 \\
Work Motivation $\left(\mathrm{X}_{2}\right)$ & 2.683 & 1.701 & 0.004 \\
\hline
\end{tabular}

Testing the first hypothesis using a partial test ( $t$-test) obtained the tcount value of the organizational culture variable ( $\left.\mathrm{X}_{1}\right)$ of 4.020 . Because the value of $t$ count $>t^{\text {table }}(4.020>1.701)$, then Ho is rejected and $\mathrm{H}_{1}$ is accepted, meaning that the path analysis coefficient is significant, so it can be said that the direct influence given by the organizational culture variable partially on the performance of lecturers is declared significant, while the second hypothesis testing uses partial test (t-test) obtained tcount value of work motivation variable $\left(\mathrm{X}_{2}\right)$ of 2.683 . Because the value of tcount $>t^{\text {table }}(2.683>$ 
1,701 ), then Ho is rejected and $\mathrm{H}_{1}$ is accepted, meaning that the path analysis coefficient is significant, so it can be said that the direct effect given by the work motivation variable partially on the lecturer's performance is declared significant.

The third hypothesis testing using the simultaneous test (F test) obtained the following values:

Table 4. Ftest to test the effect of $\mathrm{X}_{1}$ and $\mathrm{X}_{2}$ simultaneously against $\mathrm{Y}$ ANOVA $^{a}$

\begin{tabular}{ccccccc}
\hline & Model & Sum of Squares & Df & Mean Square & F & Sig. \\
\hline \multirow{4}{*}{1} & Regression & 3739.556 & 2 & 1869.778 & 9.662 &. oo1 $^{\text {b }}$ \\
& Residual & 5225.244 & 27 & 193.528 & & \\
\hline
\end{tabular}

a. Dependent Variable: $Y$

b. Predictors: (Constant), $\mathrm{X}_{2}, \mathrm{X}_{1}$

Based on the results of this simultaneous test (F test) through the Anova test, Fcount of 9.662 was obtained with a significance level of 0.001 . The influence given simultaneously is declared significant because the coefficient value of Fcount > Ftable (9.662 > 3.35), then Ho is rejected and H1 is accepted, meaning that there is a significant influence between organizational culture and work motivation simultaneously on lecturer performance.

\section{DISCUSSION}

\section{The influence of organizational culture on lecturer performance}

The results of the path analysis on the first hypothesis prove that organizational culture has a direct influence on lecturer performance with a path coefficient value of 0.703 , meaning that the direct effect is $70.30 \%$, and the tcount coefficient value is 4.020 . Based on these findings, it shows that organizational culture is an important aspect in determining lecturer performance. Some expert opinions are of the view that organizational culture is an important part in realizing organizational values, as stated by Fred C. Lunenburg and Allan C. Ornstein "Once an organizational culture is created, a number of mechanisms help solidify the acceptance of the values and ensure that the culture is maintained or reinforced (organizational socialization)". Likewise, K.B. Everald. Geoffrey Morris and Ian Wilson stated "however, 
organizations can be said to consist of four interdependent elements...the elements are as follows: technology, structure, people, and culture" .

In relation to the performance of lecturers, Samsu quoted Azyumardi Azra as stating that lecturers are staff who have a very noble profession, because education is one of the central themes, the Prophet Muhammad himself is often referred to as an educator of mankind. Azyumardi Azra quotes Dr. Syed Hossein Nasr and his friends at the first Islamic Education Conference in Mecca in 1977 concluded that as a central figure in education, lecturers must be exemplary in their morals, in addition to their scientific and academic abilities, in addition to shaping their students into knowledgeable and moral people.

Some of the theories above show the relationship between organizational culture and performance, and have encouraged lecturers to carry out their functions in the context of forming morals and scientific integrity. This study proves that there is a significant direct influence between organizational culture on the performance of lecturers at the Islamic Education Management Study Program, Faculty of Tarbiyah and Teacher Training, Sulthan Thaha Saifuddin State Islamic University Jambi.

\section{The influence of work motivation on lecturer performance}

Based on the findings, it shows that work motivation is an important aspect in determining lecturer performance. In the view of Fred C. Lunenburg and Allan C. Ornstein, work motivation is defined as "those processes within an individual that stimulate behavior and channel it in ways that should benefit the organization as whole".

From this view, in terms of content, it can be understood that motivation relates to how to identify specific factors that can motivate someone to realize their performance. Meanwhile, from the process side, motivational factors interact to produce motivation. This is in line with Samsu's view, if it is understood that the motivation that exists in a lecturer is a driving force that will realize a behavior in order to achieve its goals, then the basic motivation for most people to become lecturers in a particular organization is to earn a living, meaning that if one On the other hand, people 
use their knowledge, skills, energy and part of their time to work for an organization, on the other hand they expect to receive certain rewards.

Based on the Samsu theory above, it shows that this study proves that the aspect of work motivation has a significant effect on lecturer performance. This means that the motivation for lecturers who serve in the Islamic Education Management Study Program at the Tarbiyah and Teacher Training Faculty of UIN Sulthan Thaha Saifuddin Jambi is good. From the opinion above, it is clear that there is an influence given by work motivation on the performance of lecturers.

\section{The influence of organizational culture and work motivation on lecturer performance}

The results of the path analysis prove that organizational culture and work motivation simultaneously have a significant direct effect on lecturer performance with a direct effect of 0.417 or $41.70 \%$, and the Fcount coefficient value of 9.662. There are other factors that also have a significant influence beyond the factors studied, for example leadership styles in the form of participatory leadership styles, laissez faire, authoritarian, democratic, charismatic, transformational, situational, trust, managerial grid, and threedimensional leadership.

Based on the existing findings, showing the existence of a good organizational culture accompanied by good work motivation is also an important aspect of lecturer performance. These two aspects simultaneously play a very important role in realizing the performance of lecturers at the Islamic Education Management Study Program, Faculty of Tarbiyah and Teacher Training at UIN Sulthan Thaha Saifuddin Jambi. In addition, the research also proves that organizational culture and work motivation simultaneously affect lecturer performance. High-performing lecturers are proven to be influenced by organizational culture factors and work motivation, supported by ideological understanding with the presence of the Islamic concept of work.

The organizational culture is often interpreted as a philosophy that guides the policies of employees and customers. In the context of organizational culture, the Qur'an as a guide to life, always lives with the flow of change and progress. The Qur'an provides instructions with all its 
explanations in accordance with the culture, atmosphere, and human will. However, in understanding the verses of the Qur'an, especially at the level of implementation, the meaning of the verses of the Qur'an is often only seen as doctrinal-transcendental, not culturally-profane. The spirit of the Qur'an is not introduced in a dialogical manner with the social realities that bind life. In practice, the Quran provides a spirit for humans and organizational culture to grow and develop in a better direction. The Qur'an has encouraged education and various social institutions to continue to develop a good organizational culture such as a maximum work culture, paying wages before the sweat dries up, working together, and so on.

Work motivation is owned by every human being, although in the context of work there are some people who work harder than others. Generally, people want to work harder, if there is no difficulty in realizing it. As long as the work drive is strong, the greater the individual's opportunity to achieve his goals. There are even those who like the encouragement of work without reward, because they feel happy and happy doing their job. The Islamic concept of the world as an investment in the hereafter, places material not as a goal, but a means of realizing prosperity, as stated in the Holy Quran, surah alQashshash verse 77, which means "and seek (reward) the land of the hereafter with what Allah has bestowed upon you. to you, but do not forget your share in the world and do good (to others) as Allah has done good to you, and do not do mischief on the earth. Indeed, Allah does not like those who do mischief."

The findings obtained in this study are in line with Hanny Aulia Utami, et al, who prove that organizational culture and work motivation have a positive and significant effect on employee performance at PT Perkebunan Nusantara III (Persero) Medan. Likewise, Haryo Kusumo who proves that organizational culture has a significant and positive effect on employee performance, organizational commitment. It can be concluded that many studies have proven that organizational culture and work motivation have a direct and significant effect on performance as well as on lecturers at the Islamic Education Management Study Program, Faculty of Tarbiyah and Teacher Ttraining, UIN Sulthan Thaha Saifuddin Jambi. 


\section{CONCLUSION}

From the findings and the proposed hypothesis, it proves that the culture created by the organization has a direct and significant influence on the performance of lecturers at the Islamic Education Management Study Program, Faculty of Tarbiyah and Teacher Training at UIN Sulthan Thaha Saifuddin Jambi. Values, norms, and beliefs, as well as rituals and symbols regarding the existing organizational culture show a very significant influence on the performance of lecturers. Likewise, work motivation has a direct influence on the performance of lecturers at the Islamic Education Management Study Program, Faculty of Tarbiyah and Teacher Training at UIN Sulthan Thaha Saifuddin Jambi. Organizational culture and work motivation have a direct and significant effect on the performance of lecturers at the Islamic Education Management Study Program, Faculty of Tarbiyah and Teacher Training at UIN Sulthan Thaha Saifuddin Jambi. This indication shows that the higher the organizational culture and work motivation given, the higher the influence given to the lecturer's performance.

\section{REFERENCES}

Ali, Suryadharma. (2013). Mengawal Tradisi Meraih Prestasi: Inovasi dan Aksi Pendidikan Islam. Malang: UIN Maliki Press.

Amirullah dan Hanafi Rindyah. (2002). Pengantar Manajemen. Yogyakarta: Graha Ilmu.

Anwar, Kasful. (2011). Kepemimpinan Pesantren: Menawarkan Model Kepemimpinan Kolektif dan Responsif. Jambi: STS Press.

Azra, Azyumardi. (1998). Esei-esei Intelektual Muslim dan Pendidikan Islam. Jakarta: Logos Wacana Ilmu.

Bush, Tony. (2003). Theories Educational Leadership and Management. 3rd edition. London: Sage Publication.

Bush, Tony \& David Middlewood. (2005). Leading and Managing People in Education. California: Sagu Publication Limited.

Fahmi, Irham. (2011). Manajemen: Teori, Kasus, dan Solusi. Bandung: Alfabeta.

Fatah, Nanang. (2003). Landasan Kependidikan. Bandung: PT Remaja Rodaskarya.

Hasibuan, Malayu SP. (2003). Organisasi dan Motivasi. Jakarta: PT Bumi Aksara.

K.B. Everald. Geoffrey Morris dan Ian Wilson, 2004. Effective School Management.Fourth Edition, London: Paul Chapman Publishing. 
Kusumo, Haryo. (2017). "Pengaruh Budaya Organisasi dan Motivasi Kerja terhadap Kinerja Karyawan dengan Komitmen Organisasi sebagai Variabel Moderasi pada STEKOM Semarang." Jurnal Nusamba, 2(2).

Lunenburg, Fred C. dan Allan C. Ornstein. (200o). Educational Administration: Concepts and Practices. USA: Wadsworth/Thomson Learning.

Rivai, Veithzal dan Deddy Mulyadi. (2012). Kepemimpinan dan Perilaku Organisasi. Jakarta: Rajawali Pers.

Robbins, Steppen P. (2003). Perilaku Organisasi. (Terj. Bahasa Indonesia) Edisi ke-10. Klaten: PT. Intan Sejati.

Ruki, Achmad S. (2001). Sistem Manajemen Kinerja. Jakarta: Gramedia Pustaka Utama.

Samsu. (2014). Manajemen dan Kepemimpinan Pendidikan. Jambi: Pusaka.

Samsu and Rusmini. (2016). "The influence of principals' leadership styles on school innovation in Jambi (Case study in several senior high schools in Jambi)." Al-Ta lim Journal, 23(1).

Schabracq, Marc. (2007). Changing Organizational Culture. England: John Wiley \& Sons Ltd. The Atrium, Southern Gate, Chichester, West Sussex PO19 8SQ.

Scherin, Edgar H. (2004). Organizational Culture and Leadership. San Francisco, California: Jossey Bass, Third Edition.

Schoefer, Susan Davidson. (1977). The Motivation Process. Massachussets: Winthrop Publisher, Inc.

Steers, Richard M. and Lymann W. Porter, (2003). Motivation and Work Behavior. New York : Mc Graw-Hill, Inc.

Undang-Undang RI Nomor 14 Tahun 2005 Tentang Guru dan Dosen.

Utami, Hanny Aulia. Hendry. Sonia. \& Jelmy. (2019). "Pengaruh Budaya Organisasi dan Motivasi Kerja terhadap Kinerja Karyawan pada PT. Perkebunan Nusantara III (Persero) Medan." Wahana Inivasi: Jurnal Penelitian dan Pengabdian Masyarakat UISU, 8(1).

Wibowo. (2010). Manajemen Kinerja. Jakarta: Rajawali Pers.

Winardi. (2002). Motivasi dan Permotivasian dalam Manajemen. Jakarta: PT Raja Grafindo Persada. 